\title{
NECoM (Numerically Enhanced COnceptual Modelling) of two small Maltese Aquifers: Mizieb and Pwales
}

\section{NECoM (Numerically Enhanced COnceptual Modelling, Modellazione Concettuale Numericamente Assistita) di due piccoli acquiferi maltesi: Mizieb e Pwales}

Francesca Lotti, Iacopo Borsi, Enrico Guastaldi, Alessio Barbagli, Paolo Basile, Lorenzo Favaro, Adrian Mallia, Rachel Xuereb, Michael Schembri, Julian Alexander Mamo, Francesco Demichele, Manuel Sapiano

Francesca LOTTI 茟”"

TEA SISTEMI S.p.A., Pisa (Italy)

SYMPLE s.r.l., Vetralla, Viterbo (Italy)

Kataclima s.r.l., Vetralla, Viterbo (Italy)

f.lotti@kataclima.com

Iacopo BORSI

TEA SISTEMI S.p.A., Pisa (Italy)

\section{Enrico GUASTALDI}

Center for GeoTechnologies, University of Siena, San Giovanni Valdarno (Italy) GeoExplorer Impresa Sociale S.r.l., Arezzo (Italy)

CGT SpinOff S.r.l., Arezzo (Italy)

\author{
Alessio BARBAGLI \\ Center for GeoTechnologies, University of Siena, San Giovanni Valdarno (Italy) \\ GeoExplorer Impresa Sociale S.r.l., Arezzo (Italy) \\ Department of Physics and Earth Science, University of Ferrara, Ferrara (Italy) \\ Paolo BASILE \\ Lorenzo FAVARO \\ STEAM, Pisa (Italy) \\ Adrian MALLIA \\ Rachel XUEREB \\ Adi Associates Environmental Consultants Ltd, San Gwann (Malta) \\ Michael SCHEMBRI \\ Julian Alexander MAMO \\ Francesco DEMICHELE \\ Manuel SAPIANO \\ Government of Malta - Energy and Water Agency, Hal Luqa (Malta)
}

Keywords: $N E C o M$, data gap, groundwater management, archive research.

Parole chiave: NECoM, carenza di dati, gestione delle acque sotterranee, ricerca d'archivio.

Ricevuto/Received: 25 January 2021 - Accettato/Accepted: 22 March 2021 Pubblicato online/Published online: 30 March 2021

This is an open access article under the CC BY-NC-ND license: http://creativecommons.org/licenses/by-nc-nd/4.0/

(C) Associazione Acque Sotterranee 2021
Riassunto: Lo studio ha riguardato l'analisi numerica di due piccoli acquiferi maltesi, Mizieb e Pwales, finalizzata a verificare il modello concettuale e a suggerire strategie significative per la futura rete di monitoraggio della risorsa idrica sotterranea coordinata dal Governo di Malta tramite la Energy and Water Agency (EWA). Con l'acquisizione di nuovi dati, il modello numerico sarà soggetto ad ulteriore revisione dei concetti in base ai quali è costruito, considerando lo sviluppo del modello concettuale e numerico come attività parallele ed interconnesse, piuttosto che sequenziali.

La struttura del modello numerico e la stima dei parametri si sono basate su informazioni qualitative e dati reperiti in vecchi documenti presenti negli archivi dell'EWA; le informazioni/ ipotesi sono state tradotte in "prior information", mentre le misure vere e proprie sono state indicate come classiche "osservazioni", associando un peso appropriato alla loro affidabilità. Il contenuto informativo dei dati, sia qualitativi che quantitativi, è stato valorizzato in fase di calibrazione, evidenziando le incertezze e le domande che rimangono aperte a causa dell'insufficienza dei dati.
Abstract: Two small Maltese aquifers, Mizieb and Pwales, were numerically analyzed to test the existing bydrogeological conceptual model and suggest optimized groundwater monitoring strategies in support of the forthcoming monitoring network coordinated by the Government of Malta through the Energy and Water Agency. The model will undergo further revision of the concepts on which it is based as soon as new data is available, considering the conceptual and numerical model development as parallel activities, rather than as sequential.

The model structure and parameter estimation made use of qualitative information and data acquired by archive research; during model calibration informationlassumptions were introduced as "prior information" while the available measurements were introduced as classical "observations" with proper associated weight. The information content of both qualitative and quantitative data could be assimilated along the calibration process, highlighting the uncertainties and open questions that remain because of data insufficiency. 


\section{Introduction}

The Maltese archipelago is located in the centre of the Mediterranean and comprises 3 main islands: Malta $\left(246 \mathrm{~km}^{2}\right)$, Gozo $\left(67 \mathrm{~km}^{2}\right)$ and Comino $\left(3.5 \mathrm{~km}^{2}\right)$ with a total area of 316 $\mathrm{km}^{2}$. With a population of 493,000 inhabitants (year 2019, NSO 2019), Malta is the world's fifth most densely populated country and the first in the European Union context, with an average of more than 1,500 persons per square kilometre, compared with the EU average of 117 persons per square kilometre.

The high population density and the natural shortage of water resources are a determining factor in ensuring that the Maltese islands have by far the lowest natural freshwater availability per person per year of all the EU Member States (SEWCU 2015). In fact, freshwater availability per capita is estimated to stand between the 80 and $120 \mathrm{~m}^{3}$ mark (from about 38 to 57 million $\mathrm{m}^{3}$ per year), well below the limit required to sustain basic water needs for the development of the country, which is established at $500 \mathrm{~m}^{3}$ (SEWCU 2015).

The total water demand of the Maltese islands has been estimated to reach 62 million $\mathrm{m}^{3}$ in 2014 (SEWCU 2015), surely above the natural freshwater availability. The demand of the various water using sectors is increasingly being addressed through the conjunctive use of four main water resources, namely: groundwater aquifer systems, harvesting of rainwater, desalinated sea-water and treated wastewater (locally called New Water) (SEWCU 2015).

Groundwater abstraction, from all the groundwater bodies in the Maltese Water Catchment District, was estimated to reach around 38 million $\mathrm{m}^{3}$, or $61 \%$ of the total national water demand. Seawater intrusion in the aquifer systems connected to the coast occurs as a direct and unavoidable consequence of groundwater abstraction (see for instance Jiao and Post 2019).

To assess the impact on groundwater status in the future, the $2^{\text {nd }}$ RBMP implementation will take advantage of numerical modelling to include a prediction capacity in the chain of water management decision making (SEWCU 2015). In this framework, in 2018 the Energy and Water Agency of the Government of Malta launched a new project to review existing groundwater models for the five most important aquifers of the archipelago, and to develop new numerical models, aiming at determining the sustainable yield of these aquifer systems and focusing on the salinization issue.

The objective of this paper is to report details about the conceptual model review carried out in this general framework, addressing two minor Maltese aquifers located North of Malta, namely the Mizieb Mean Sea Level Aquifer (MSLA) and Pwales Coastal Aquifer (CA). This study included a thorough review and re-processing of existing data, such that the model could encapsulate as much as possible the data information content and be used to test their reciprocal coherence with the complex behaviour of the system. Data mainly included qualitative information and the purpose of the modelling process was to help in the conceptual model definition according to the data-driven approaches (see for instance Kresic and Mikszewski 2012) or the NECoM approach (Lotti et al. 2021). Simultaneously, strategies for optimal acquisition of further data were examined through the modelling process. The model was delivered to the Government of Malta through the Energy and Water Agency.

\section{Geological and hydrogeological setting}

The work presented in this paper is part of a wider study focusing on the five main aquifers in Maltese archipelago: the activity included an in-depth review of the geological and structural setting, which is the subject of a forthcoming paper (Barbagli et al., Geological and hydrogeological reconstruction of Maltese archipelago's main aquifers, unpublished paper, 2021) and summarized in this section.

From a geo-structural point of view, the Maltese islands are made up of a core of clays and marls, the Blue Clay (BC) and Globigerina Limestone (GL) formations, stacked between two permeable limestone formations known as the Upper and the Lower Coralline Limestones (UCL and LCL; Figure 1 and 2). A fifth formation, the Greensand (G) lies between UCL and BC. However, given G narrow thickness $(0-11 \mathrm{~m})$ and discontinuous distribution across the islands, it scarcely contributes to the groundwater flow and reservoir. Structurally, the islands are divided into three regions consisting of two elevated blocks (Gozo and Malta islands) separated by a graben stretching between southern Gozo (from the Ghanjsielem-Qala fault) and the northern part of Malta (till the Victoria fault), including Comino island.

\section{Mizieb and Pwales aquifers}

The Mizieb aquifer is hosted in UCL, and it is situated in the northern region of Malta (Fig. 1). The UCL reaches a maximum thickness of $97 \mathrm{~m}$ with considerable variations in porosity and permeabilities. It is bounded on the north by the Mizieb-Mistra Fault and on the south by the ManikataSimar Fault (Fig. 3). Mizieb is the largest synclinal structure in Malta. The syncline occurs on the downthrown side of the Mizieb-Mistra fault that cuts across Mellieha ridge from west to east, dissecting the northern part of Malta into several ridges and valleys. The rim of the syncline is determined by the height of the clay on its side of the fault. The lowest ground elevations occur at $15 \mathrm{~m}$ above sea level on the southern flank at Bajda Ridge overhanging Pwales valley, and $15 \mathrm{~m}$ on the eastern saddle leading to Mistra. The Blue Clay basement has been reconstructed by means of stratigraphic information (Royal Engineers 1952; Constain Ltd 1958; Government of Malta 2020) and is shown in Figure 3.

The geological and morphological setting of the area create preferential runoff converging towards the main sinkhole structure where the elevation of the Blue Clay structure is lower (Fig. 3). Groundwater flow seems to follow the same directions, with different hypotheses of discharge towards the sea. In 1945, 32 boreholes were drilled by the No. 7 Boring Section, R.E., to determine the form and capacity of the structure and to define the route by which surplus water is discharged underground to the sea (Royal Engineers 1952; Morris 1952; Rose 2012). According to Morris (1952), the only 


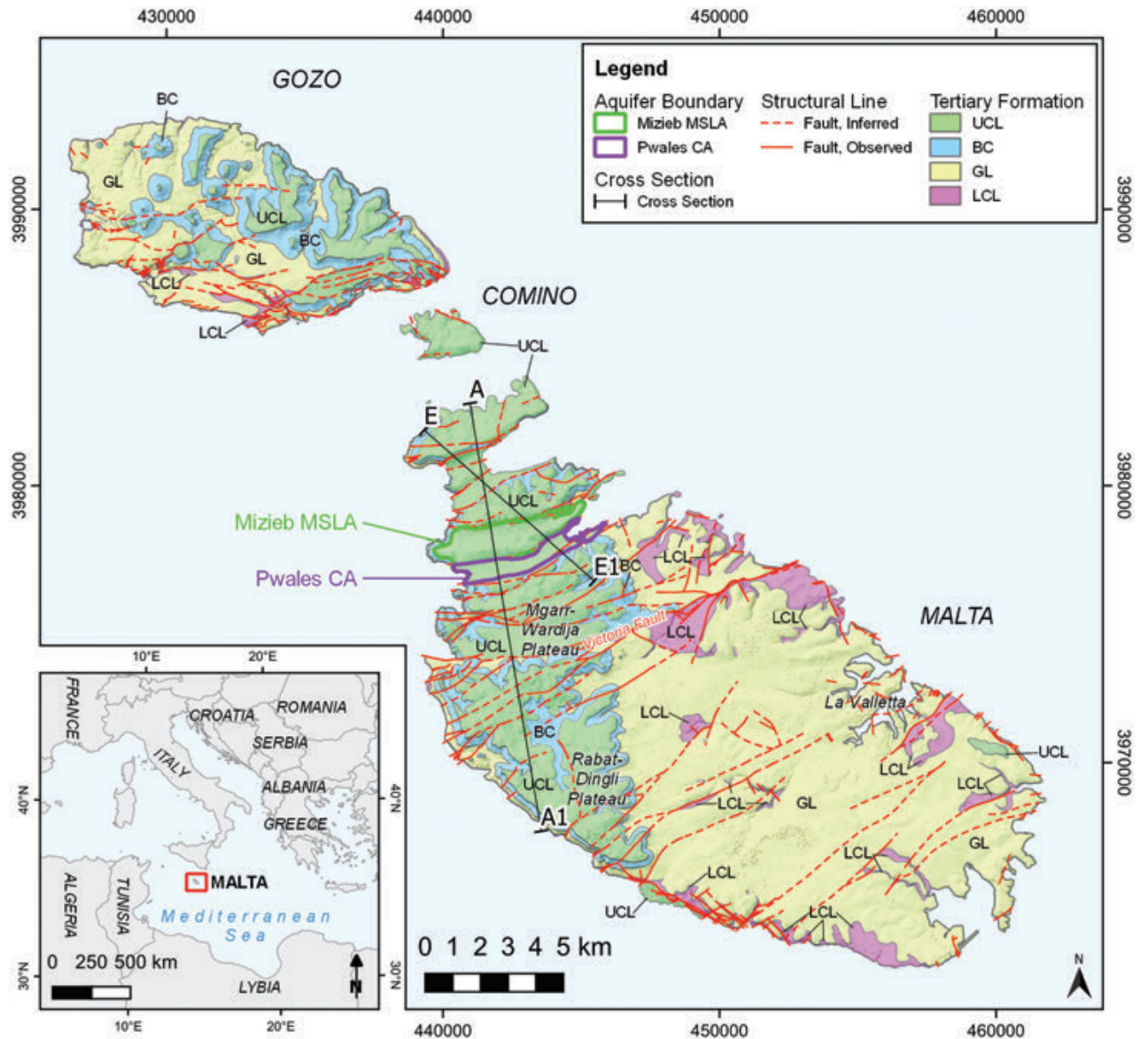

Fig. 1 - Maltese archipelago geological map (modified after OED, 1993): MSLA = Mean Sea Level Aquifer; CA = Coastal Aquifer. Coordinates of the geological map are in WGS84/UTM33N (EPSG:32633); Cross-sections are shown in Figure 2.

Fig. 1 - Carta geologica dell'arcipelago maltese (modificata da OED, 1993): MSLA = Mean Sea Level Aquifer; CA = Coastal Aquifer. Le coordinate della carta geologica sono in WGS84 / UTM33N (EPSG: 32633). Le sezioni sono mostrate nella Figura 2.

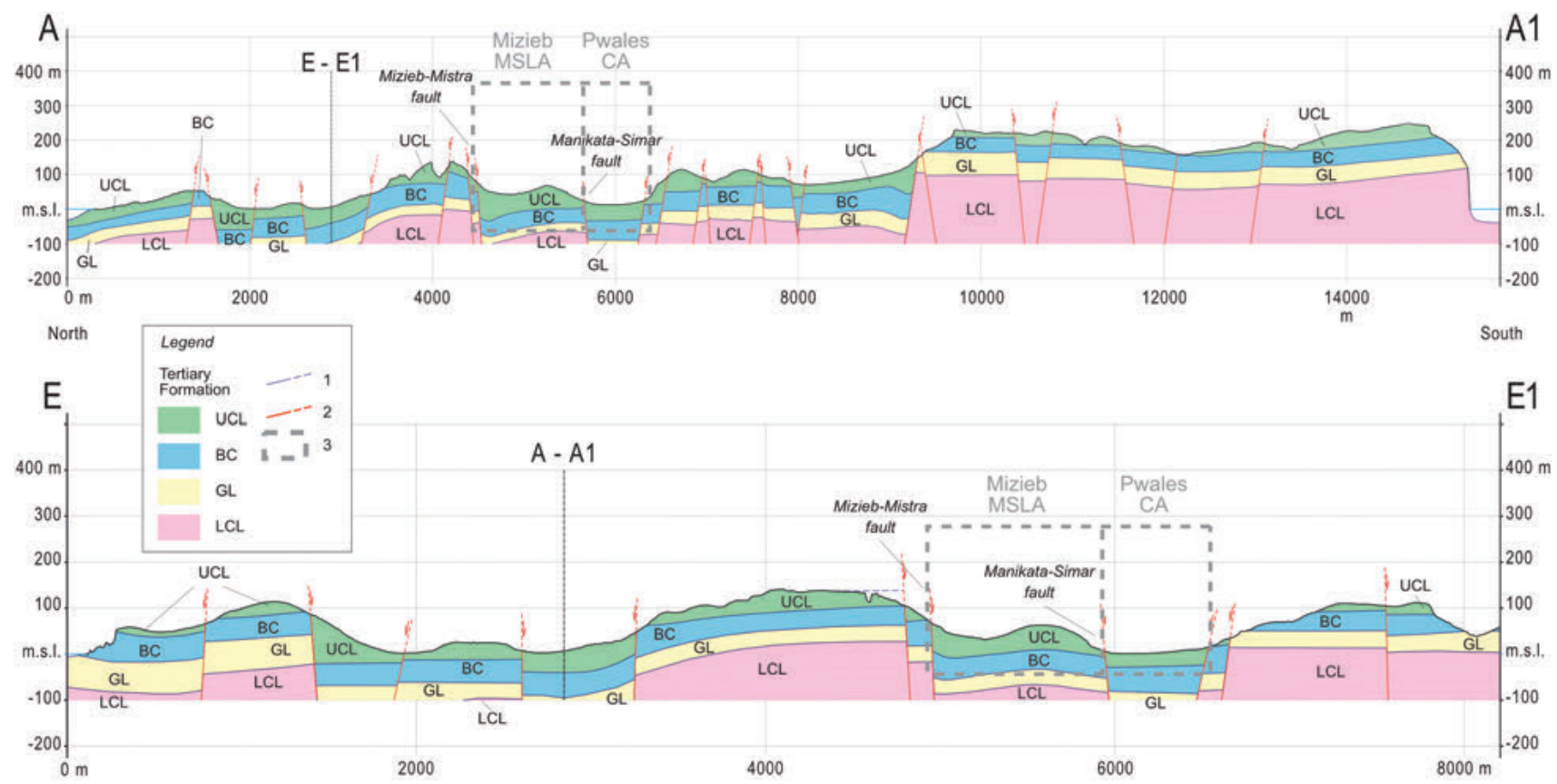

North-West

Fig. 2 - Cross-sections, modified from (Barbagli et al., Geological and bydrogeological reconstruction of Maltese archipelago's main aquifers, unpublished paper, 2021).

Fig. 2 - Sezioni, modificate da (Barbagli et al., Geological and hydrogeological reconstruction of Maltese archipelago's main aquifers, unpublished paper, 2021). 
route appeared to be northwards across the Mizieb-Mistra Fault, along which he postulated the clay seal was breached. In 1958, the Soil Mechanics Department of Richard Costain Ltd performed specific investigations to determine other possibilities of leakage and the basin overall storage capacity as a reservoir (Constain Ltd 1958). Another possible way out of groundwater was discovered in the lower part of the syncline, which turned out to be open to seawater by means of three sinkholes (Figs. 3 and 4). These sinkholes, with a diameter of
$90 \mathrm{~m}$, extend through the UCL, penetrate and breach the clay to $-40 \mathrm{~m}$ below sea level bringing the saturated zone in direct contact with seawater. According to Constain Ltd (1958) "it is considered that the leakage from Mizieb is taking place through the sinkholes and not across the fault or elsewhere. The three sinkholes that have been located all lie along the northern margin of the basin, i.e. close to the Mizieb-Mistra Fault. This strip of country has been fairly thoroughly investigated and it is not thought that any more sinkholes exist here".
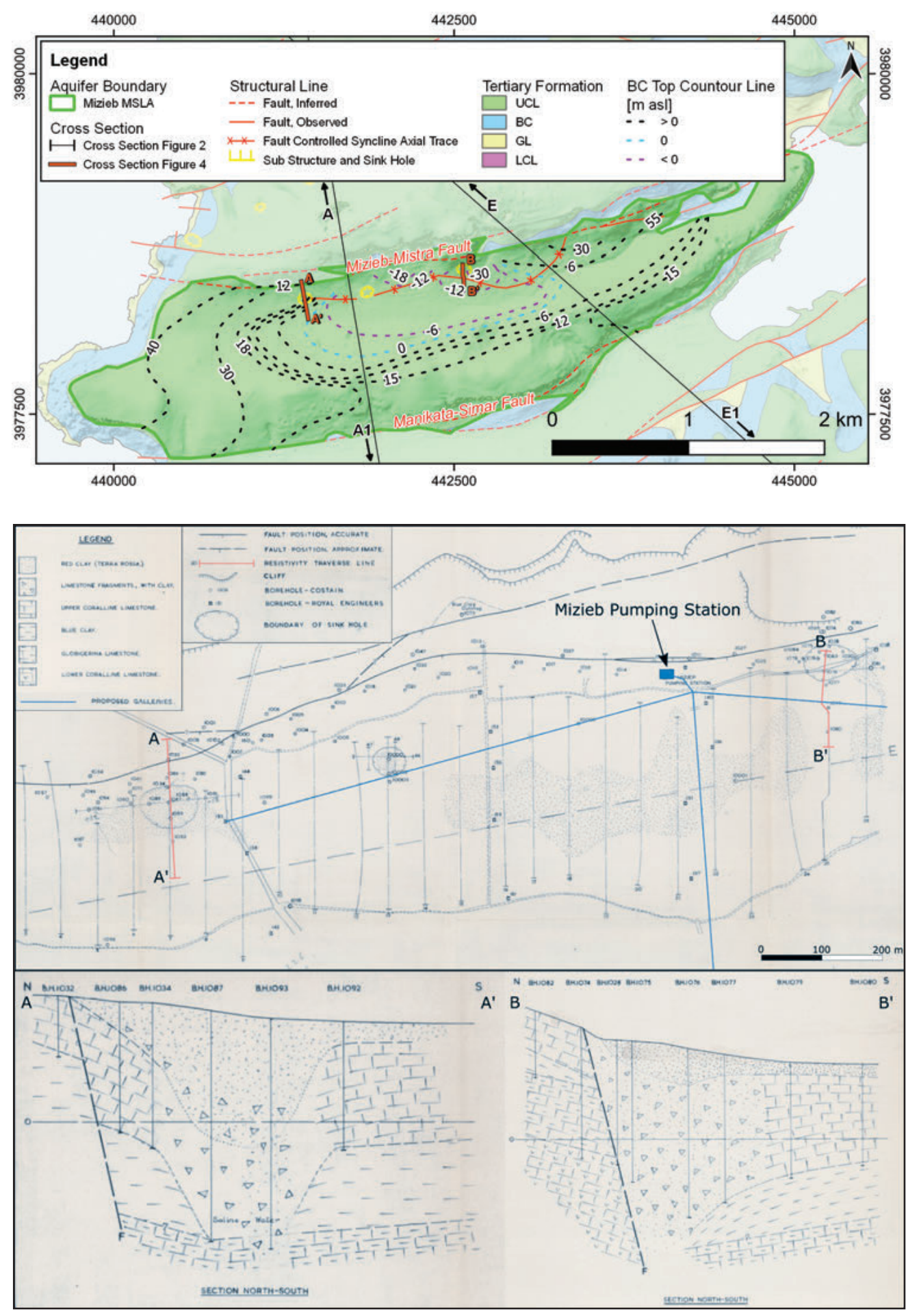

Fig. 3 - Mizieb MSLA geological map and Blue Clay elevation in $m$ asl obtained processing the stratigraphic information (Royal Engineers 1952; Constain Ltd 1958; Government of Malta 2020).

Fig. 3 - Mappa geologica di Mizieb MSLA e quota del tetto delle BC in $\mathrm{m}$ s.l.m., ottenuta elaborando le informazioni stratigrafiche (Royal Engineers 1952; Constain Ltd 1958; Government of Malta 2020).
Fig. 4 - Karst sinkbole discovered west of Ciantar's wine factory (cross section $\left.A-A^{\prime}\right)$ and Karst sinkhole discovered at Dar (cross section B-B'); (Costain Ltd 1958).

Fig. 4 - Sinkhole scoperto a ovest della fabbrica di vino di Ciantar (sezione A-A') e sinkhole scoperto a Dar (sezione B-B '); (Costain Ltd 1958). 


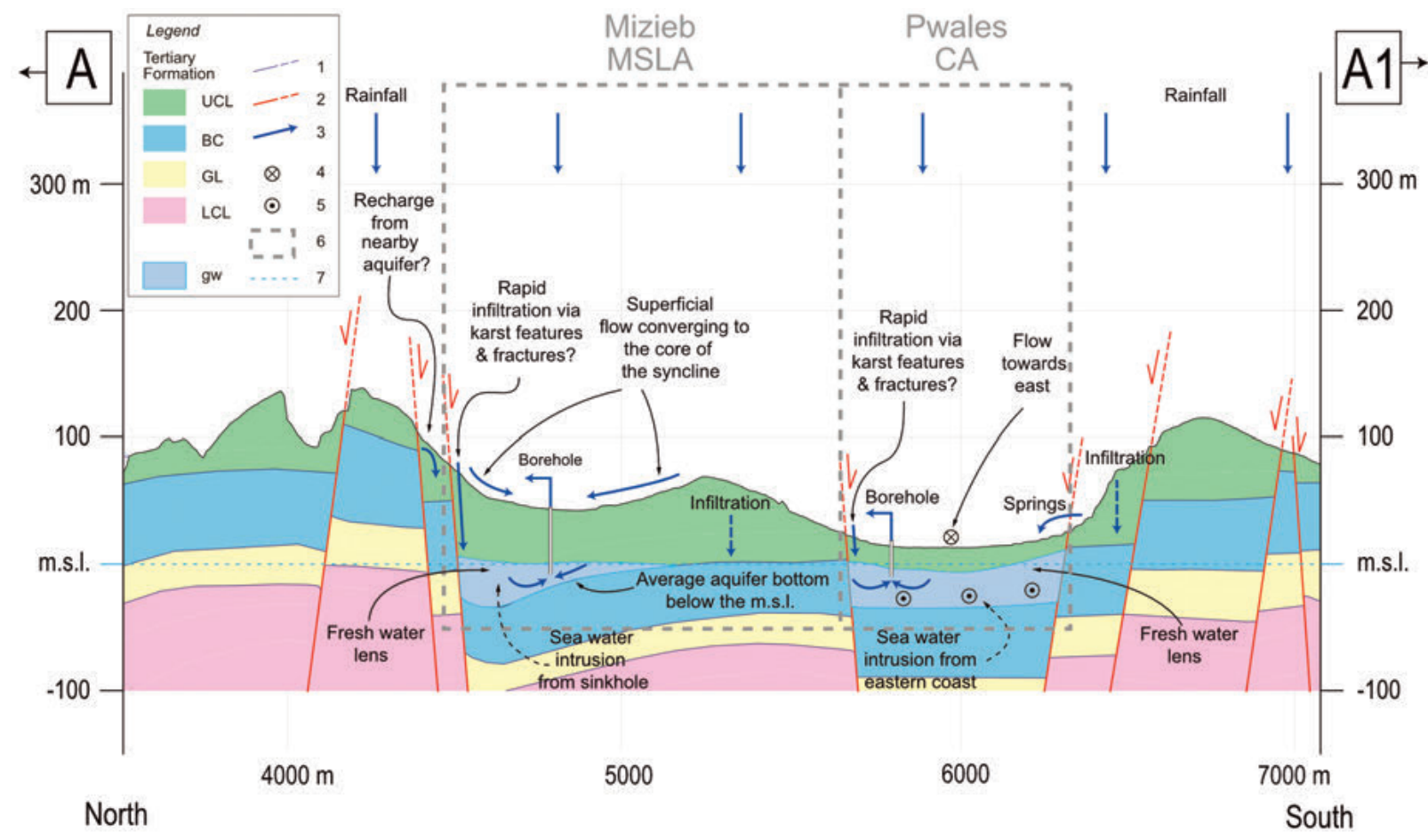

Fig. 5 - Mizieb and Pwales aquifers bydrogeological conceptual scheme across section A-A1 (Fig. 3): filled polygons - bydrogeological units; 1 - bydrogeological units contacts; 2 - faults (observed or inferred); 3 - flow directions; 4 - superficial and groundwater flowpath towards the eastern sea coast; 5 - Sea water intrusion from the eastern coast; 6 - Areas of interest; 7 - Sea level.

Fig. 5 - Schema idrogeologico delle falde acquifere di Mizieb e Pwales nella sezione A-A1 (Figura 3): poligoni pieni - unità idrogeologiche; 1 - contatti unità idrogeologiche; 2 - faglie (osservate o supposte); 3 - direzioni di flusso; 4 - percorso delle acque superficiali e sotterranee verso la costa del mare orientale; 5 Intrusione di acqua di mare dalla costa orientale; 6 - Aree di interesse; 7 - Livello del mare.

According to the considerations shown above, the conceptual model for the Mizieb mean sea-level aquifer assumes (Fig.5):

- the Upper Coralline Limestone aquifer is present in the basin with an extension around $5.2 \mathrm{~km}^{2}$;

- the aquifer rests on the impermeable $\mathrm{BC}$, except at the sinkholes where the aquifer is delimited at the bottom by the Globigerina Limestone;

- its lateral boundaries are the Mizieb-Mistra Fault at north, the Manikata-Simar Fault at south, the outcropping or shallow impermeable Blue Clay at east and west;

- the water table is controlled by the sinkhole and/or by the northern fault;

- the aquifer is susceptible to seawater intrusion due to the sinkhole breaching the $\mathrm{BC}$ and placing in contact the freshwater with the seawater;

- the natural recharge of the aquifer is due to the precipitation and the mean annual rainfall is about 550 $\mathrm{mm}$; possibly, additional recharge is due to runoff from Millieha Ridge;

- water abstraction is for potable supply and irrigation.

The Pwales aquifer forms a low block $\left(2,8 \mathrm{~km}^{2}\right)$ between the Wardija and the Bajda Ridges, with its base rising slightly above sea level in the west, resulting in a limited area perched above sea level, while to the east the $\mathrm{BC}$ formation dips below sea level and the aquifer is in direct contact with the sea (Figs. 5 and 6).

The Pwales area is one of the most fertile valleys of the Malta Islands and the intensive agriculture activity is maintained by abundant irrigation water. The water body occurs within a downthrown syncline of UCL which sits over clay at an altitude of $21 \mathrm{~m}$ asl in the western side near Ghajn Tuffieha whilst it dips below sea-level to a depth of around - $30 \mathrm{~m}$ asl at the eastern side along Xemxija bay (Fig. 6).

Close to Xemxija bay, the aquifer is heavily exploited for irrigation purposes. The valley receives, at several points, freshwater discharge from a number of springs discharging over the clay such as the Ballut springs, the springs of Wardija and Ghajn Nastas.

Structurally the valley is a narrow syncline dipping to the east between two faults bounding Wardija Ridge to the south and Bajda Ridge to the north.

Salinity intrusion processes differ from the Malta MSLA, which is constituted by a lens of freshwater floating over seawater. In Malta MSLA, seawater predominantly affects the aquifer by vertical intrusion where up-coning of salty water intrudes the freshwater lens at the basal interface. Because of the different geological setting of Pwales, intrusion occurs here in the form of a quasi-horizontal tongue of seawater spreading from east to west. The wells located at the western edge of the valley are least susceptible to seawater intrusion as the clay is elevated above sea-level (Fig. 6).

The natural recharge of the aquifer is due to the precipitation and the mean annual rainfall is about $550 \mathrm{~mm}$. Additional recharge is given by the runoff from the northern and southern hills. The discharge of the aquifer is the eastern coast and the water abstraction whose purpose is mainly irrigation. 


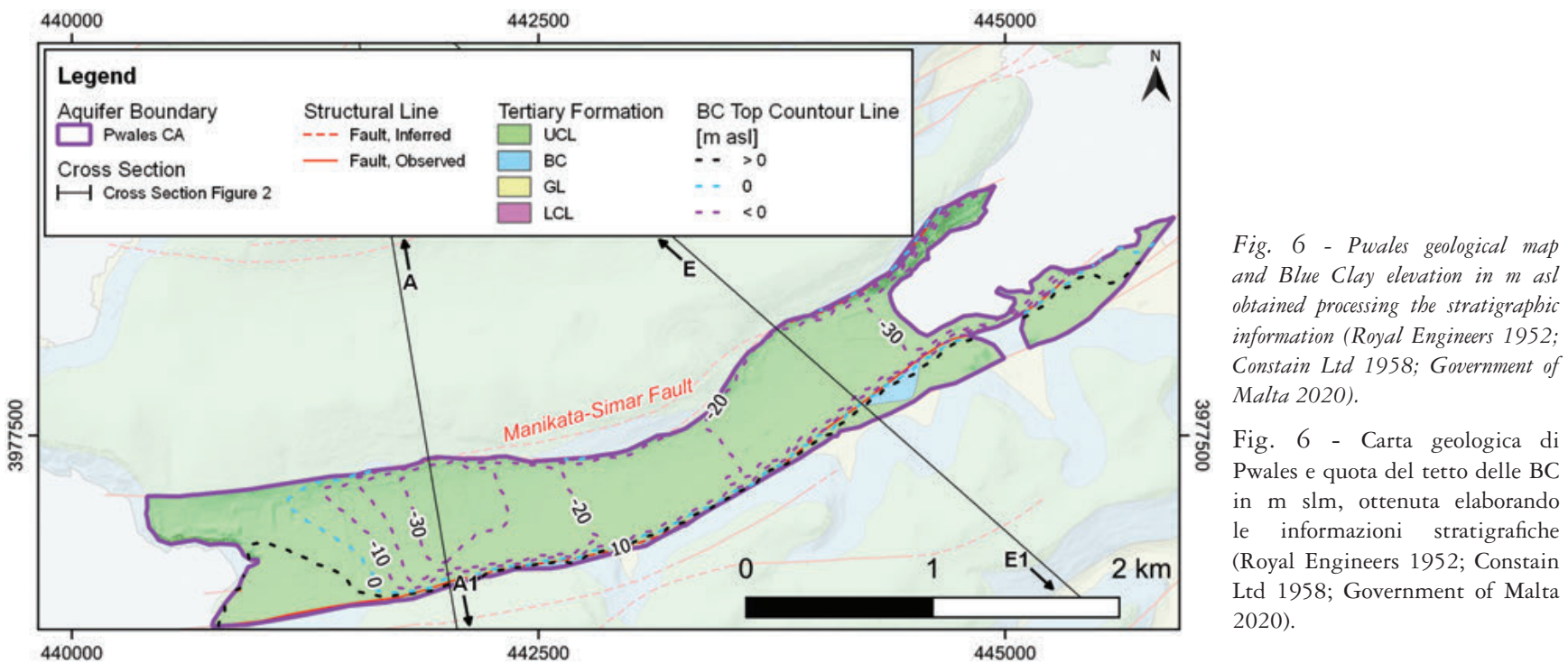

\section{Available data}

In both aquifers, measured data are scarce and dated, but an attempt of model calibration was performed based on the information reported in the Royal maps (1945), in Constain Ltd (1958) for Mizieb and collected in the 1940 census for Pwales (EWA unpublished data) (Fig. 7). The model structure and parameter estimation made use of both qualitative and quantitative information; narrative descriptions and assumptions were introduced as "prior information" while the available heads measurements were introduced as "observations".

The work of Constain Ltd reports hydraulic head elevations measured in different months between 1957 and 1958 during the Mgarr gallery works (started in 1957 and completed in 1962). The gallery shafts are connected to the Mizieb Pumping Station as shown in Figura 4.
The dataset used, anyway, is affected by high uncertainty for the following reasons:

1. Heads are based on single measurements;

2. Measured heads report no information about local water density or electrical conductivity; heads could not undergo the freshwater head correction that would be necessary especially in Pwales;

3. Borehole elevation in $\mathrm{m}$ asl is known, but it is not possible to know the uncertainty associated with the elevation data;

4. Borehole position in space is approximative and deduced by georeferencing the old maps;

5. Active pumping during the measurement period are unknown;

6. Measurements are taken in different seasons and years;

7. The bottom of the aquifers is not exactly known.

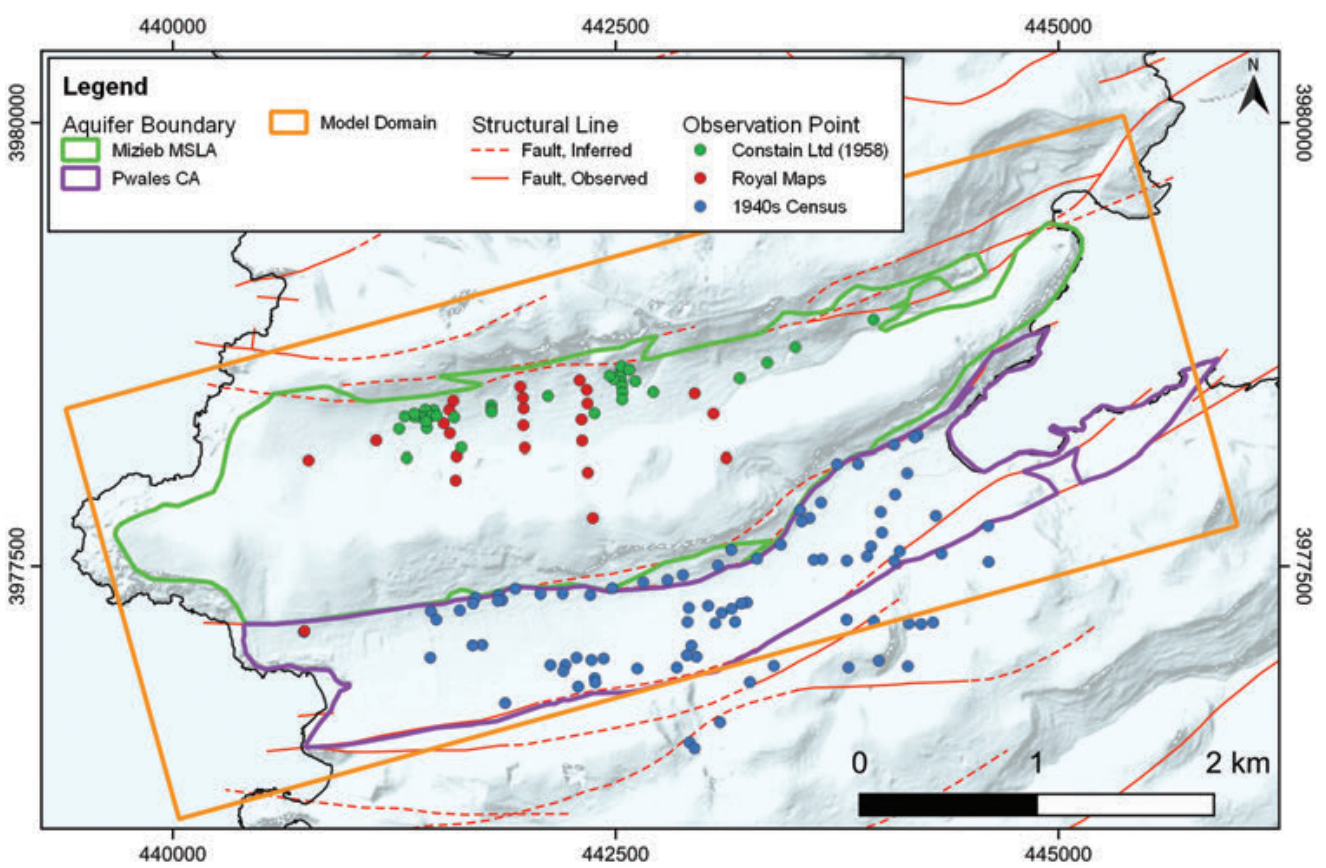

Fig. 7 - Extension of model domain and observation points from the Royal maps (1945), Constain Ltd (1958) and 1940 census.

Fig. 7 - Estensione del dominio del modello e punti di osservazione derivanti dalle Royal maps (1945), Constain Ltd (1958) e dal censimento del 1940. 
Calculation of the average water balance was performed on the basis of the 1940-1960 time series of precipitation and temperature, which revealed a mean annual cumulative rainfall of about $555 \mathrm{~mm}$, and an average temperature of $18.9^{\circ} \mathrm{C}$.

Regarding the estimate of evapotranspiration terms, available information about the island soils distribution (Lang 1960; Fig. 8) allowed to apply the Thornthwaite method (Thornthwaite and Mather 1955), as summarized in the following steps:

1. Definition of a spatialized index of Available Water Capacity (AWC): the different soils (Lang 1960) were analyzed in terms of approximate thickness (intended as the depth reached by the roots) and grain size. The soils were then grouped according to the prevailing textural composition and associated to the pertinent AWC, according to the USDA procedure (USDA 1999).

2. Calculation of the average annual Actual Evapotranspiration (AET) using the Thornthwaite method in association with the previously calculated AWC and its spatial distribution.

3. Inclusion of the influence of geology and slope: the slope correction to the infiltration coefficient associated to each lithology was applied, obtaining the CIPS values (Viaroli et al. 2018).
4. Inclusion of land use: the first available aerial photographs and related land use map is dated 1957 and can be considered coherent with the period covered by the dataset (Fig. 9).

5. Additional runoff: a recharge fringe around the $\mathrm{BC}$ outcrop was assumed. The amount of additional recharge assigned was roughly estimated considering the possible runoff over the BC outcrop. A buffer of $100 \mathrm{~m}$ was created downstream to the $\mathrm{BC}$ outcrop.

This analysis led to define a spatialized value of reference natural recharge referred to the years 1940-1960, as shown in Figure 10.

A summary of the natural balance terms expressed considering the average AWC and average $\mathrm{mm} / \mathrm{y}$ is reported in Table 1. Actual evapotranspiration (AET) was also calculated by BRGM in 1991 for the Rabat-Dingli Plateau, by means of a lumped rainfall-discharge model calibrated over springs discharges. The model considered rainfall time series from 1840 to 1991 (average $506 \mathrm{~mm} / \mathrm{y}$ ) and provided a AET of $320 \mathrm{~mm} / \mathrm{y}$. The AET percentage over precipitation (63\%), is very close to the present average result $(62.5 \%)$ calculated independently.

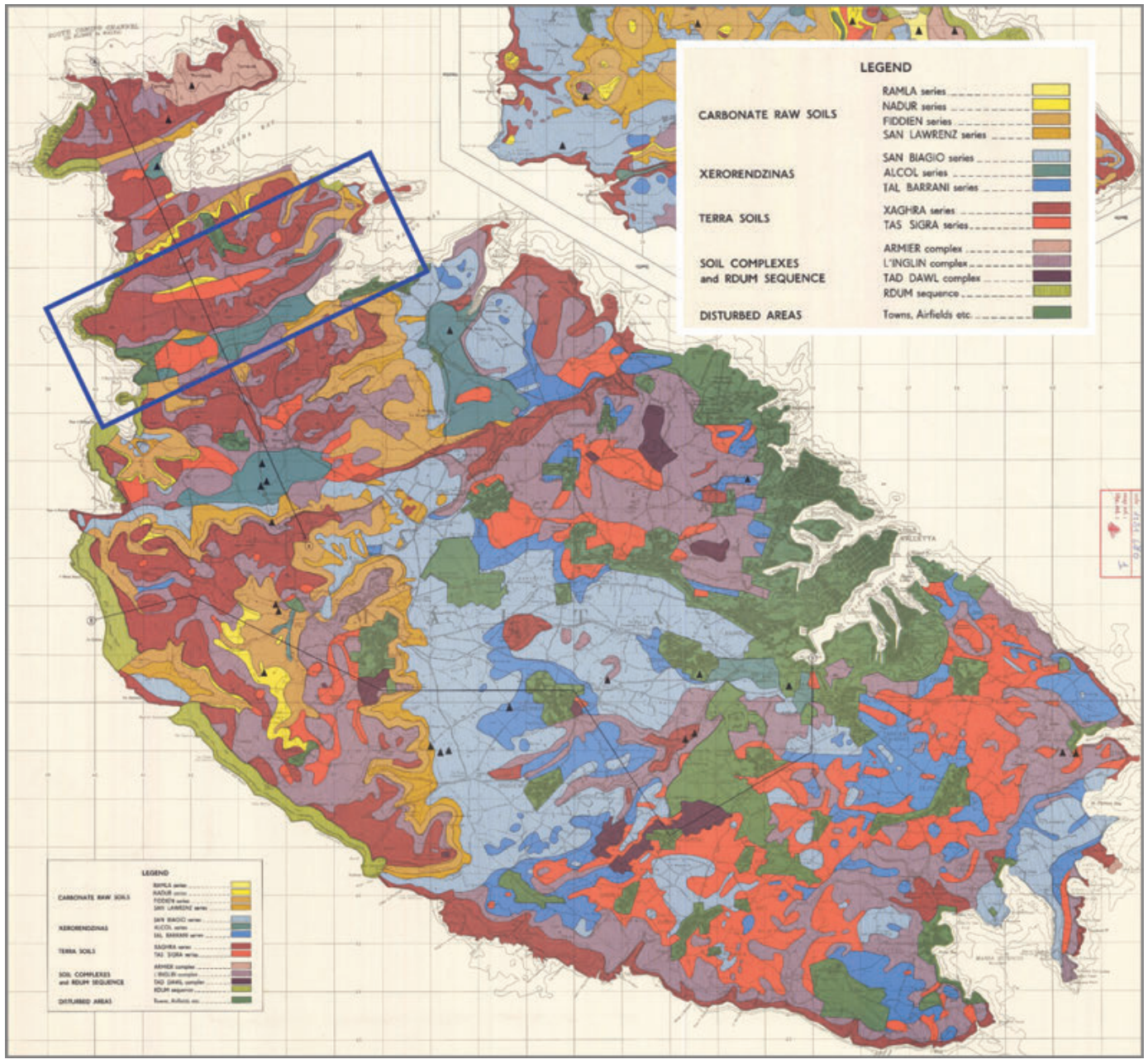

Fig. 8 - Extent and distribution of soil types in Malta as reported in Lang (1960). The reference reports detailed descriptions and data associated to each type.

Fig. 8 - Distribuzione dei tipi di suolo a Malta come riportato in Lang (1960), lavoro che riporta descrizioni dettagliate e dati associati a ciascun suolo. 

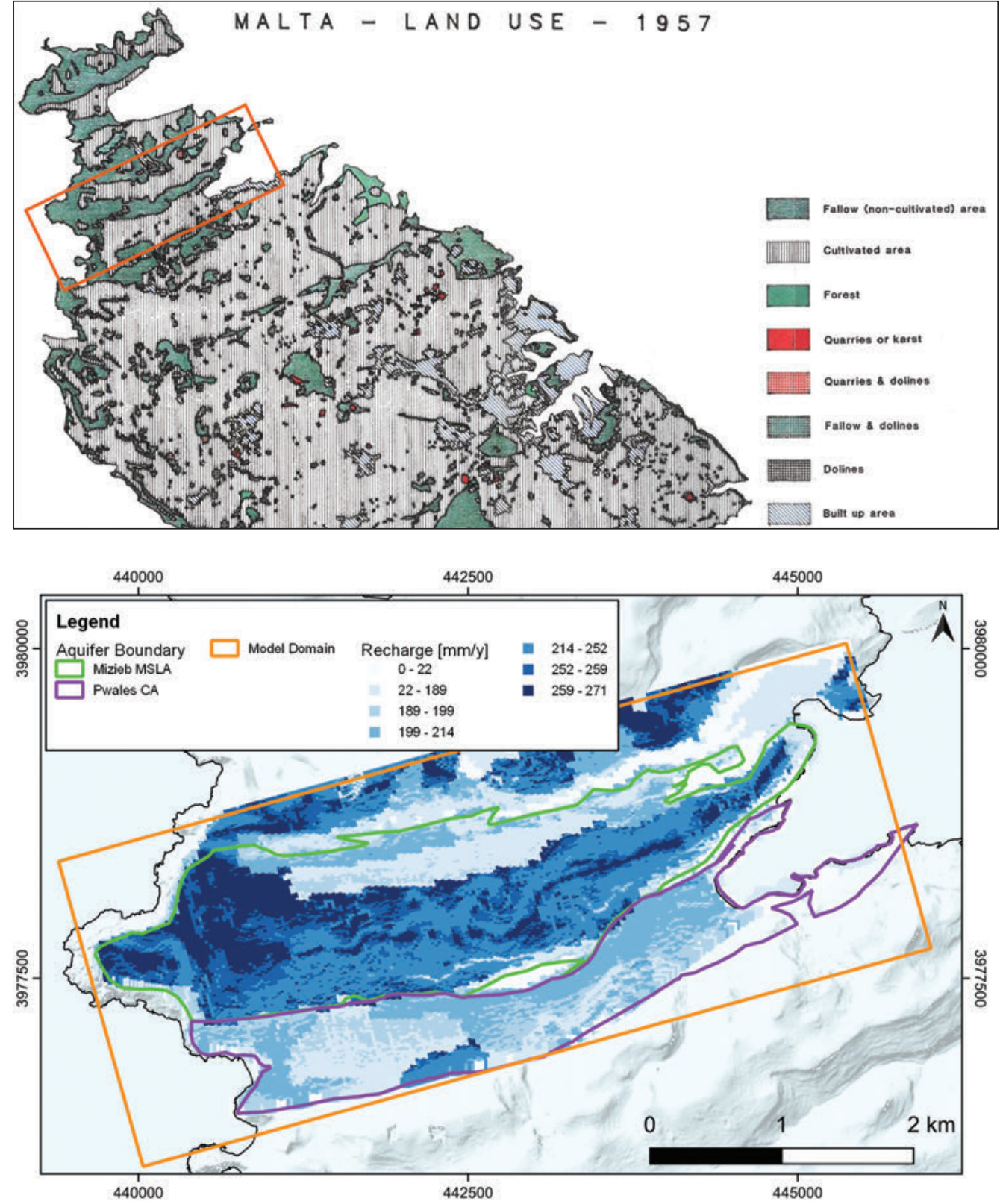

Fig. 9 - Map of land use based on the first aerial photographs (1957) provided by EWA.

Fig. 9 - Mappa dell'uso del suolo fornita da EWA, basata sulle prime fotografie aeree disponibili (1957).

Fig. 10 - Recharge spatial distribution.

Fig. 10 - Distribuzione spaziale della ricarica.

Tab. 1 - Terms of the average natural water balance over the period 1940-1960.

Tab. 1 - Termini del bilancio naturale medio nel periodo 1940-1960.

\begin{tabular}{|l|l|}
\hline \multicolumn{1}{|c|}{ Balance Term } & \multicolumn{1}{c|}{ Value } \\
\hline Temperature $\left({ }^{\circ} \mathrm{C}\right)$ & 18.9 \\
\hline Precipitation $(\mathrm{mm} / \mathrm{y})$ & 554.6 \\
\hline AET $(\mathrm{mm} / \mathrm{y})$ Thornthwaite, AWC $=46 \mathrm{~mm}$ & $346.9(62.5 \%$ of $\mathrm{P})$ \\
\hline Infiltration + Runoff $(\mathrm{mm} / \mathrm{y})$ & 207.7 \\
\hline
\end{tabular}

\section{Numerical model}

Mizieb and Pwales are separated from each other by a low conductivity fault, and Pwales is separated from Malta MSLA by Pwales fault, assumed to be perfectly impermeable. Elevations of top and bottom of the two aquifers allow to include them into a unique model, even if hydrogeological behavior is quite different.

The initial conceptual issues which were addressed through the modelling exercise included:

1. Mizieb: it is not clear which is the natural outflow of the aquifer; the basin seems to have little exchange with the outside. Costain Ltd (1958) reports that there is a leakage towards the bottom through three sinkholes crossing the Blue Clay; this hypothesis has been tested together with the outflow through the "fault breccia" along the northern fault as postulated by Morris (1952). 
2. Mizieb: the supposed groundwater discharge areas (sinkholes and/or fault) can turn into a "way in" in case the vertical hydraulic gradient between the aquifer and the sea level is inverted, with consequent seawater intrusion from the bottom of the aquifer; this could explain the chloride concentration behaviour observed in the Mizieb Pumping Station (Fig. 4): in the monitored period (1987-2009) chloride concentrations temporarily raised over $1000 \mathrm{mg} / \mathrm{l}$ in several occasions (Fig. 11).

3. Pwales: the aquifer is affected by lateral seawater intrusion because of the low depth of the aquifer bottom (top of Blue Clay). In this specific case the bottom elevation and geometry is the dominant factor controlling seawater ingression under the pumping conditions. Information is very scarce with respect to the stratigraphy and to the actual water abstraction.

The model was developed using the code MODFLOW-2005 (Harbaugh et al. 2005), applying two different modelling platform: Groundwater Vistas 7.24 (Rumbaugh and Rumbaugh, 2020) for model building and calibration, and FREEWAT (Borsi et al. 2019; De Filippis et al. 2017; Rossetto et al. 2018) for model visualization and sharing with the Agency. Data assimilation of the model was performed through the highly parameterized approach with PEST (Doherty et al. 2010a; 2010b).

\section{Domain and discretization}

The Mizieb-Pwales (MP) model grid covers an area of about $15 \mathrm{~km}^{2}$, divided into 47616 cells with dimension $12.5 \times 25 \mathrm{~m}$, rotated by 15.5 degree (Fig. 7). The Mizieb aquifer surface occupies 16000 cells, Pwales 8350, the sea 3200 cells, while the southern and western portions of the domain are limited by low conductivity formations, assuming that groundwater exchanges are extremely scarce in those directions.

The model is single-layer, with a variable thickness. The bottom elevation of the model was set according to the stratigraphic interpretation of the Blue Clay top (Figure 3 and 6), nevertheless the bottom surface needed to be smoothed in some portions in order to control numerical instability.

\section{Boundary condition}

The preliminary configuration of boundary conditions is modeled by means of the following MODFLOW packages (Fig. 12):

1. General head boundary (GHB) to represent the sea, characterized by head elevation $=0 \mathrm{~m}$ asl and a conductance of $0.001 \mathrm{~m}^{2} / \mathrm{s}$;

2. General head boundary (GHB) to represent the sinkholes at the aquifer bottom in Mizieb, characterized by head elevation $=0 \mathrm{~m}$ asl and conductance which was varied in the calibration process;

3. Drain boundary (DRN) to represent a possible outflow from the aquifer along the northern fault breccia, characterized by head elevation $=0 \mathrm{~m}$ asl and conductance which was varied in the calibration process;

4. Wells (WEL) to represent the 81 private wells that are supposed to be active during the period of reference (1940-1960) characterized by an estimated average discharge of about 10,000 $\mathrm{m}^{3} / \mathrm{y}$ each;

5. Hydraulic Flow Barrier (HFB) to represent the main faults discontinuities with an initial low hydraulic conductivity $(1 \mathrm{E}-8 \mathrm{~m} / \mathrm{s})$.

Along the data assimilation process, an additional fault was included updating the previous conceptual model, as described later on.

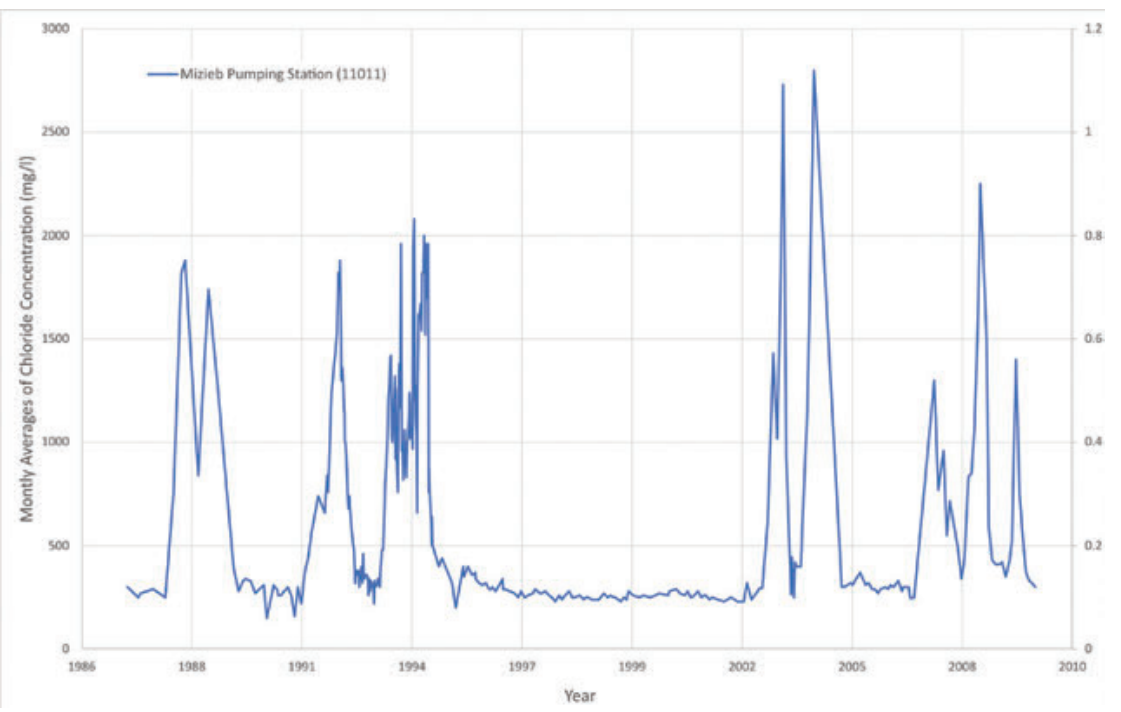

Fig. 11 - Monthly averages of chloride concentration monitored at the Mizieb Pumping Station in the period 1987-2009; the pumping station location is shown in Figure 4 together with the connected galleries. The bottom elevation of the pumping shaft is at - $13 \mathrm{~m}$ asl; in the period 1987-2009 the average yearly pumped volume was $34,571 \mathrm{~m}^{3}$ ( $25^{\circ}$ percentile $=30,000 ; 75^{\circ}$ percentile $\left.=42,000\right)$.

Fig. 11 - Medie mensili delle concentrazioni di cloruri monitorate presso la Stazione di Pompaggio di Mizieb nel periodo 1987-2009; la posizione della stazione di pompaggio è mostrata in Figura 4 insieme alle gallerie collegate. La quota inferiore della camera in cui è attivo il pompaggio si trova a - $13 \mathrm{~m}$ slm; nel periodo 1987-2009 il volume medio annuo estratto è stato di $34.571 \mathrm{~m}^{3}\left(25^{\circ}\right.$ percentile $=30.000 ; 75^{\circ}$ percentile $\left.=42.000\right)$. 

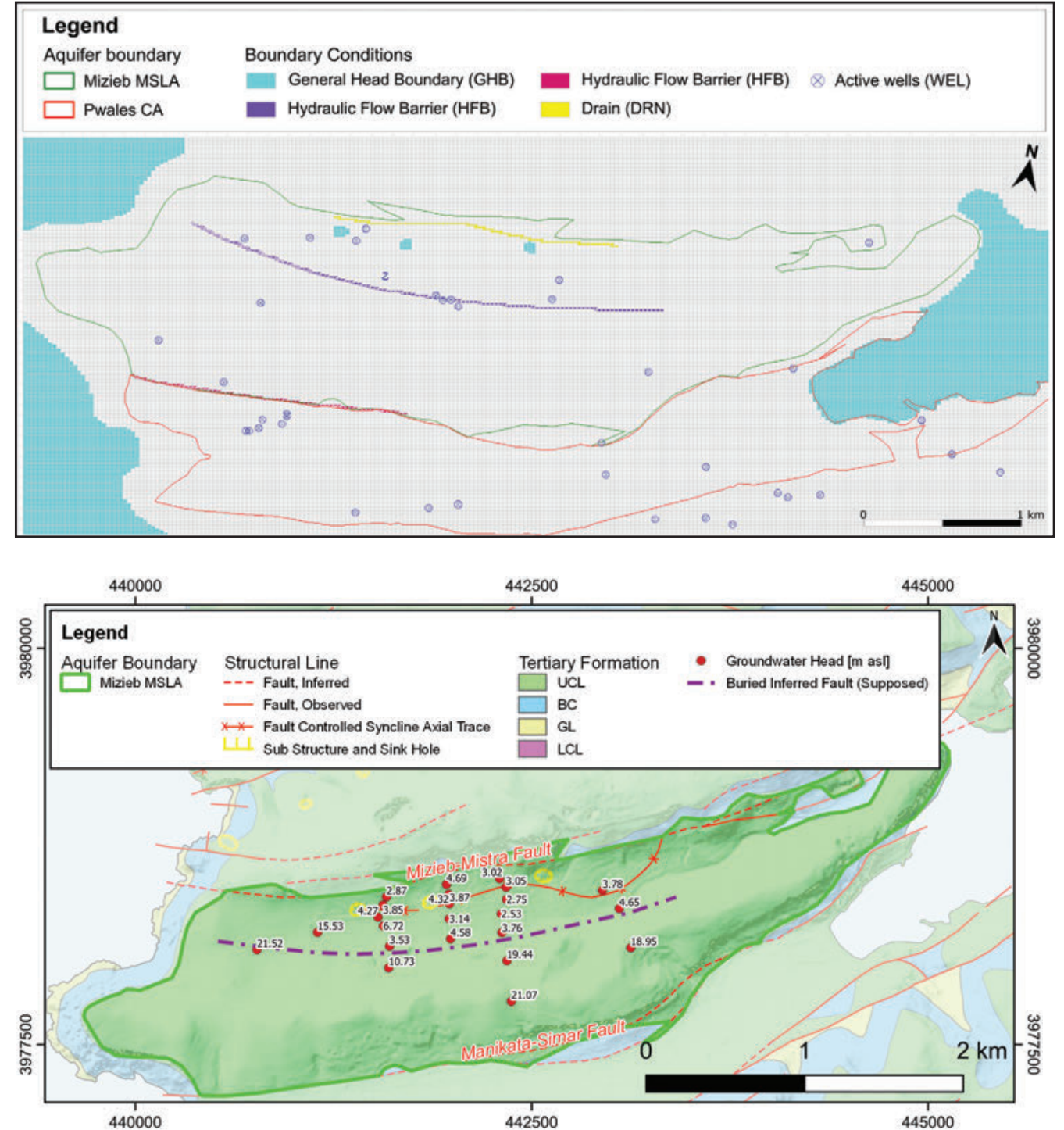

Fig. 12 - Boundary conditions of MP model, included the new supposed fault (Fig. 13) represented by the HFB boundary condition.

Fig. 12 - Condizioni al contorno del modello MP, inclusa la nuova faglia presunta (Fig. 13) rappresentata dalla condizione al contorno HFB.
Fig. 13 - Supposed new fault in Mizieb. The fault was introduced into the model in order to reproduce the head differences observed between the northern and southern side of the fault, hard to obtain without the introduction of a discontinuity.

Fig. 13 - Presunta nuova faglia a Mizieb. La faglia è stata introdotta nel modello in modo da riprodurre le differenze di carico idraulico osservate tra il lato nord e sud della faglia, difficilmente ottenibili senza l'introduzione di una discontinuità.

\section{Calibration}

Calibration of the steady state model was performed through the highly parameterized approach (Doherty et al. 2010a; 2010b). Highly parameterized (HP) groundwater models are characterized by having more parameters than those that can be estimated uniquely on the basis of a given calibration dataset, having more parameters than observations. Such models are commonly referred to as "ill posed". Illposed models require an approach to model calibration and uncertainty different from the traditional methods typically used with well-posed models (Hill and Tiedeman 2007). Regularized inversion has been suggested as an approach to obtain a unique calibration from the fundamentally nonunique, highly parameterized family of calibrated models. Regularized inversion problems are most addressed by use of the code PEST (Doherty 2008; 2015) in conjunction with pilot points as a spatial parameterization device (Doherty 2003). Two approaches of mathematical regularization (described in Doherty 2015) have been combined in the present work:
- Singular Value Decomposition (SVD): technique which separates the estimable parameter from the inestimable ones (i.e., those that are not supported by any piece of information). The estimable parameters are then combined to form the so-called super parameters set; this reduces the number of parameters to be handled, making the inverse problem mathematically solvable;

- Tikhonov regularization: it makes the values of the parameters to deviate as little as possible from a preferred value, unless they are not in contrast with observed data. A series of parameter prior information equations (which can include qualitative information expressed in mathematical terms) are used as a kind of "parameter observation" to be used by PEST along the calibration process. When regularization is applied, an additional Objective Function is created, comparing the observed and simulated values, where the "observations" are the preferred value of parameters. The aim of calibration in this case is to minimize both the measurement and parameters Objective Functions. 
Initial hydraulic conductivity values were assigned on the basis of qualitative information, bibliographic values of UCL hydraulic conductivities and results obtained in the MSLA model calibration (Lotti et al. 2021) (Fig. 14 and Tab. 2). Recharge was assigned according to the previously described water balance (Fig 10); it was varied along the calibration as a multiplier, respecting the initial relative spatial distribution.

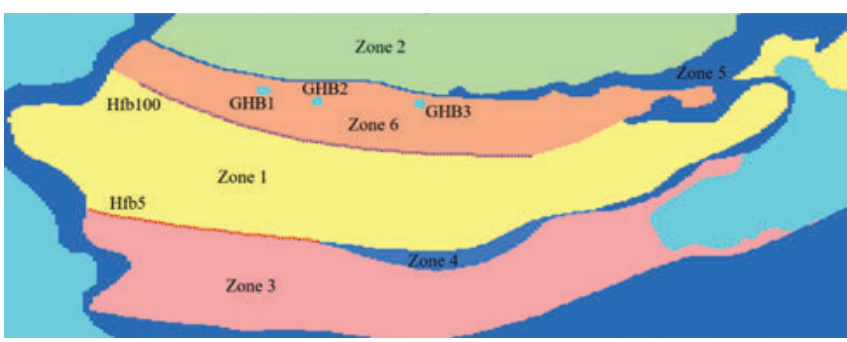

Fig. 14 - Hydraulic conductivity zones and parameters associated to GHB and HFB boundary conditions.

Fig. 14 - Zone di conducibilità idraulica e parametri associati alle condizioni al contorno GHB e HFB.

Tab. 2 - Parameters initial values.

Tab. 2 - Valori iniziali dei parametri.

\begin{tabular}{|l|l|l|l|}
\hline Name & type & Value & Unit \\
\hline GHB1 & Sinkhole conductance & $1 \mathrm{E}-5$ & $\mathrm{~m}^{2} / \mathrm{s}$ \\
\hline GHB2 & Sinkhole conductance & $1 \mathrm{E}-5$ & $\mathrm{~m}^{2} / \mathrm{s}$ \\
\hline GHB3 & Sinkhole conductance & $1 \mathrm{E}-5$ & $\mathrm{~m}^{2} / \mathrm{s}$ \\
\hline Hfb100 & Fault hydraulic conductivity & $1 \mathrm{E}-8$ & $\mathrm{~m} / \mathrm{s}$ \\
\hline Hfb5 & Fault hydraulic conductivity & $1 \mathrm{E}-8$ & $\mathrm{~m} / \mathrm{s}$ \\
\hline $\mathrm{dr} 1$ & Breccia Fault hydraulic conductivity & $1 \mathrm{E}-8$ & $\mathrm{~m} / \mathrm{s}$ \\
\hline $\mathrm{kx} 1$ & Hydraulic conductivity, zone 1 or PP & $5 \mathrm{E}-4$ & $\mathrm{~m} / \mathrm{s}$ \\
\hline $\mathrm{kx} 2$ & Hydraulic conductivity, zone 2 or PP & $5 \mathrm{E}-4$ & $\mathrm{~m} / \mathrm{s}$ \\
\hline $\mathrm{kx} 3$ & Hydraulic conductivity, zone 3 or PP & $5 \mathrm{E}-4$ & $\mathrm{~m} / \mathrm{s}$ \\
\hline $\mathrm{kx} 4$ & Hydraulic conductivity, zone 4 or PP & $1 \mathrm{E}-7$ & $\mathrm{~m} / \mathrm{s}$ \\
\hline $\mathrm{kx} 5$ & Hydraulic conductivity, zone 5 or PP & $1 \mathrm{E}-7$ & $\mathrm{~m} / \mathrm{s}$ \\
\hline $\mathrm{k} x 6$ & Hydraulic conductivity, zone 6 or PP & $5 \mathrm{E}-4$ & $\mathrm{~m} / \mathrm{s}$ \\
\hline $\mathrm{rm} 1$ & Recharge multiplier & 1 & -- \\
\hline
\end{tabular}

\section{Results}

\section{Zone calibration}

The adjustable parameters of the preliminary calibration included wide zones of hydraulic conductivity $(\mathrm{kx} 1-\mathrm{kx} 6)$, the sinkholes conductance (GHB1-GHB3), HFB conductivity of low permeability faults (Hfb5, Hfb100), breccia fault conductance (drl) and the recharge multiplier (rm1) (Tab. 2). Sensitivities are reported in Figure 15 and Table 3. The highest values of sensitivity are associated with the HFB conductivity of the fault that separates Mizieb from Pwales (Hfb5). The scatterplot with the comparison of the simulated heads with the available data is shown in Figure 16. The uniformity of the hydraulic conductivity value in zone calibration does not allow to represent the aquifer heterogeneity; especially nearby the coast (heads lower than 1-2 m asl) calculated heads are

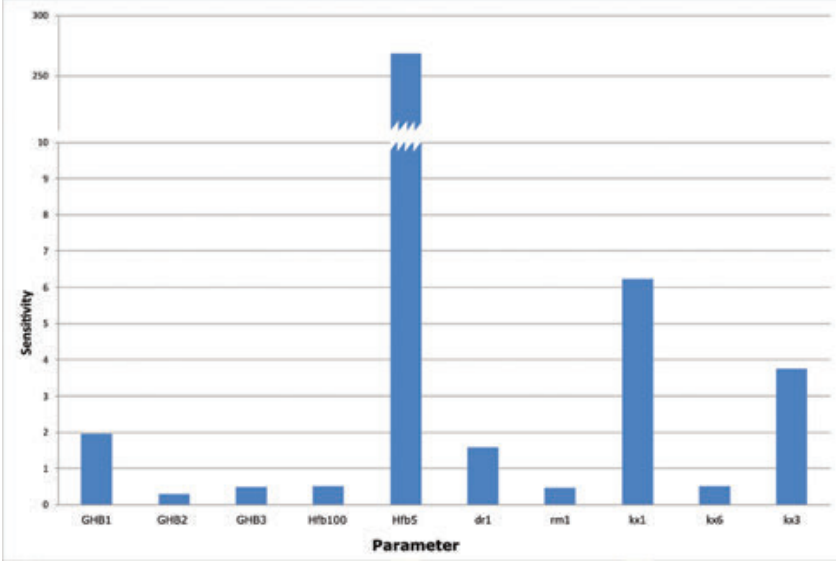

Fig. 15 - Parameter sensitivities dominated by the Manikata-Simar fault conductivity (Hbf5). Fig. 15 - Sensitività dei parametri tra cui domina la conducibilità della faglia Manikata-Simar (Hbf5).

Tab. 3 - Parameter sensitivities and preliminary values.

Tab. 3 - Sensitività dei parametri e valori preliminari.

\begin{tabular}{|c|c|c|c|c|}
\hline Name & type & Value & Unit & Sensitivity \\
\hline GHC1 & Sinkhole conductance & $6.88 \mathrm{E}-04$ & $\mathrm{~m}^{2} / \mathrm{s}$ & 1.95399 \\
\hline GHB2 & Sinkhole conductance & $8.31 \mathrm{E}-06$ & $\mathrm{~m}^{2} / \mathrm{s}$ & 0.299683 \\
\hline GHB3 & Sinkhole conductance & $4.02 \mathrm{E}-04$ & $\mathrm{~m}^{2} / \mathrm{s}$ & 0.487705 \\
\hline Hfb100 & $\begin{array}{l}\text { Fault hydraulic } \\
\text { conductivity }\end{array}$ & $4.20 \mathrm{E}-09$ & $\mathrm{~m} / \mathrm{s}$ & 0.51565 \\
\hline $\mathrm{Hfb5}$ & $\begin{array}{l}\text { Fault hydraulic } \\
\text { conductivity }\end{array}$ & $1.26 \mathrm{E}-09$ & $\mathrm{~m} / \mathrm{s}$ & 268.649 \\
\hline $\mathrm{dr} 1$ & $\begin{array}{l}\text { Breccia Fault hydraulic } \\
\text { conductivity }\end{array}$ & $9.27 \mathrm{E}-06$ & $\mathrm{~m} / \mathrm{s}$ & 1.57563 \\
\hline $\mathrm{kx} 1$ & $\begin{array}{l}\text { Hydraulic } \\
\text { conductivity, zone } 1\end{array}$ & $4.97 \mathrm{E}-05$ & $\mathrm{~m} / \mathrm{s}$ & 6.22476 \\
\hline $\mathrm{kx} 2$ & $\begin{array}{l}\text { Hydraulic } \\
\text { conductivity, zone } 6\end{array}$ & $4.45 \mathrm{E}-05$ & $\mathrm{~m} / \mathrm{s}$ & 0.513294 \\
\hline $\mathrm{kx} 3$ & $\begin{array}{l}\text { Hydraulic } \\
\text { conductivity, zone } 3\end{array}$ & $6.53 \mathrm{E}-04$ & $\mathrm{~m} / \mathrm{s}$ & 3.75376 \\
\hline $\mathrm{rm} 1$ & Recharge multiplier & 0.824099 & -- & 0.463828 \\
\hline
\end{tabular}

dominated by the GHB condition representing the sea level in Pwales, as it can be seen from the biased cluster of data at the origin of the axis (Figure 16).

\section{Pilot Point calibration}

A second round of calibration was performed keeping the same hydraulic conductivity zones, but introducing internal variability through the use of Pilot Points (pp). The other parameters were kept unchanged from the previous calibration run. The position and sensitivity of $\mathrm{pp}$ is shown in Figure 17; areas with a single pp are meant to maintain a uniform value (pp66 in the northern aquifer with no data; pp67 and pp68 associated to Blue Clay outcrops). It can be noticed that the highest value of sensitivity is associated to 


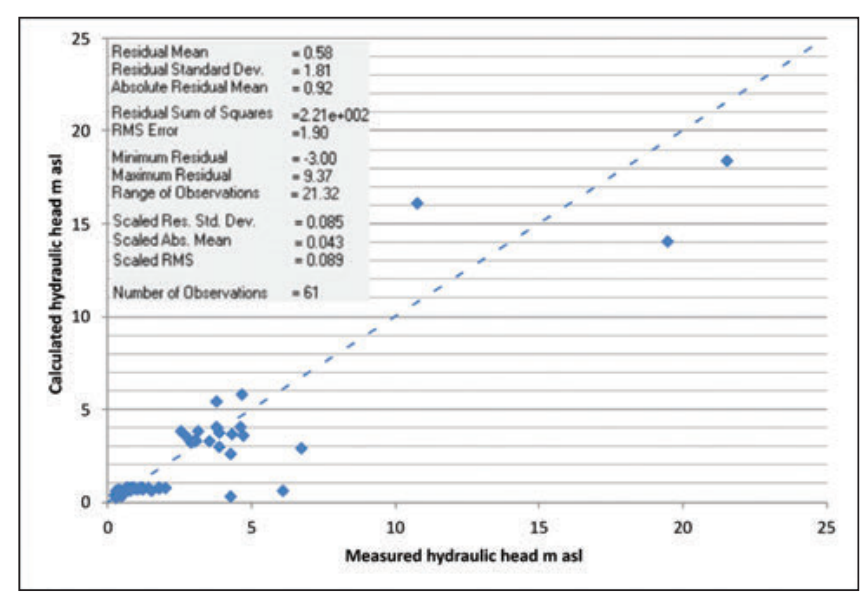

Fig. 16 - Scatterplot of calculated and observed hydraulic heads and statistics.

Fig. 16 - Grafico dei valori simulati vs osservati e relative statistiche. pp50. The spatial distribution of the hydraulic conductivity field obtained from the pp value adjustments (in $\mathrm{m} / \mathrm{s}$ ) in this steady state parameter adjustment is shown in Figure 18. The purpose of this parameter field is not to provide a "calibrated" hydraulic conductivity field, but simply to highlight possible incongruencies in model structure, as it can be seen in the western area where pp75 and pp63 generate two "bubbles" with opposite extremes of hydraulic conductivity value. Figure 19 shows the final scatterplot which still presents evidence of biases, especially in the central area of Pwales, where some of the pp with highest sensitivities are found (pp50, pp55, pp54, pp41, pp46). The hydraulic heads residuals associated to each point are shown in Figure 20, where a systematic overestimate of head values in the central-eastern portion of the aquifer can be observed.

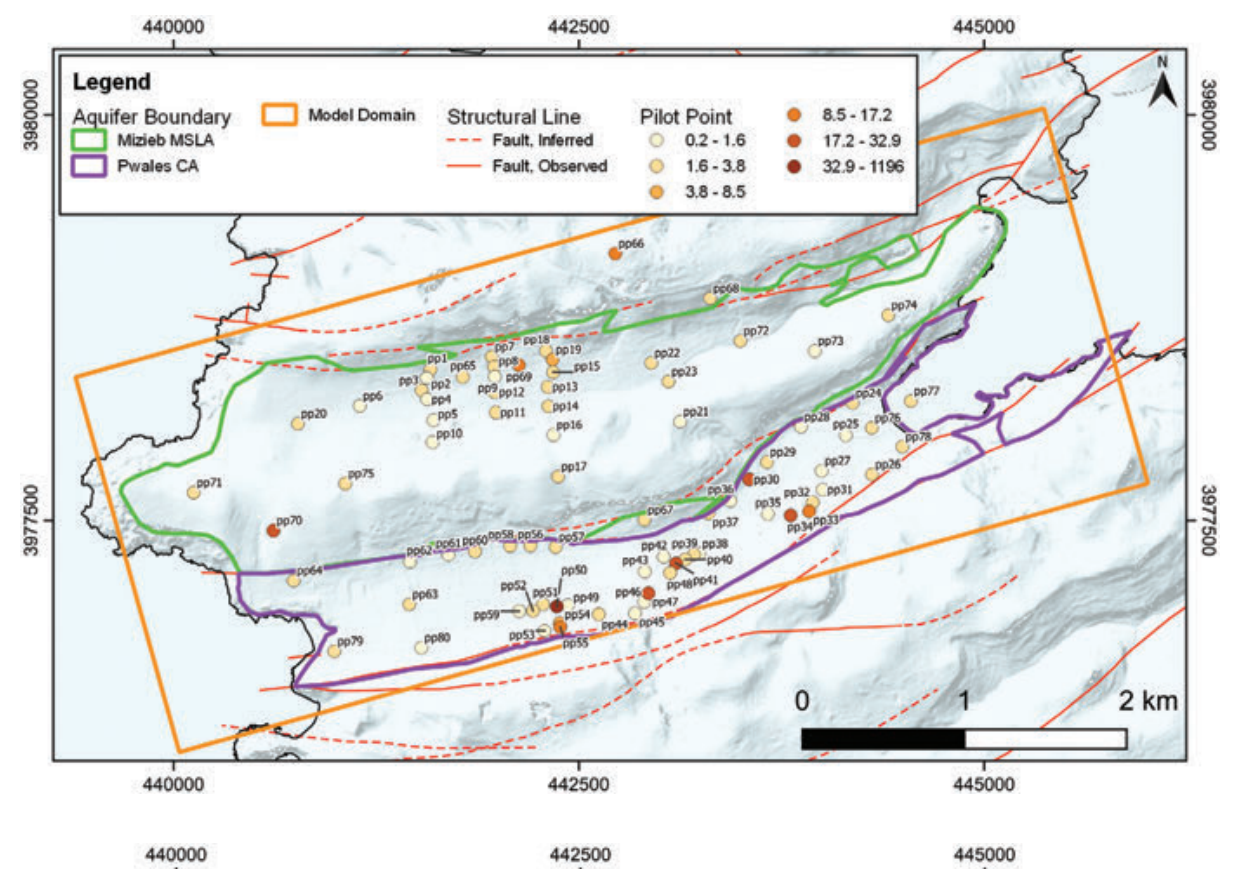

Fig. 17 - Position and sensitivities of Pilot Points. Fig. 17 - Posizione dei Pilot Points e sensitività.

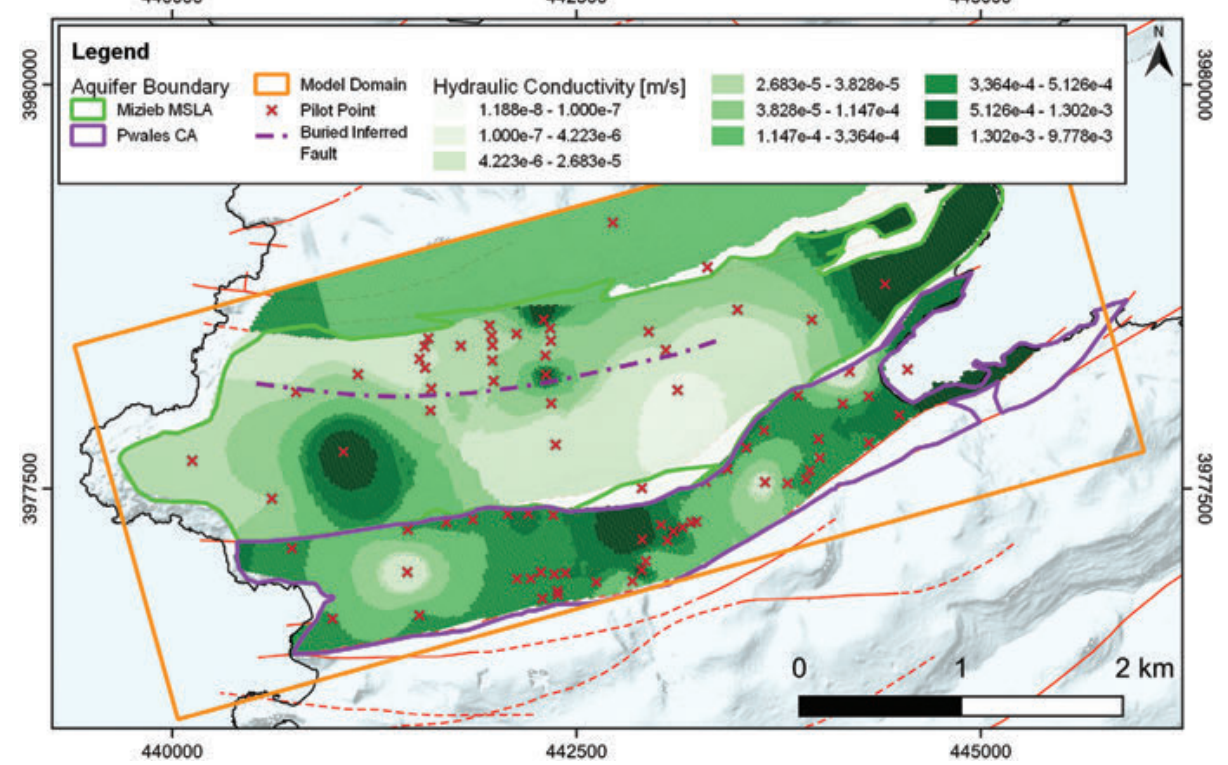

Fig. 18 - Hydraulic conductivity distribution and its incongruencies obtained from the $p p$ value adjustments (in $\mathrm{m} / \mathrm{s}$ ).

Fig. 18 - Distribuzione spaziale della conducibilità idraulica (in $\mathrm{m} / \mathrm{s}$ ) ed incongruenze evidenziate dall'aggiustamento dei valori dei pp. 


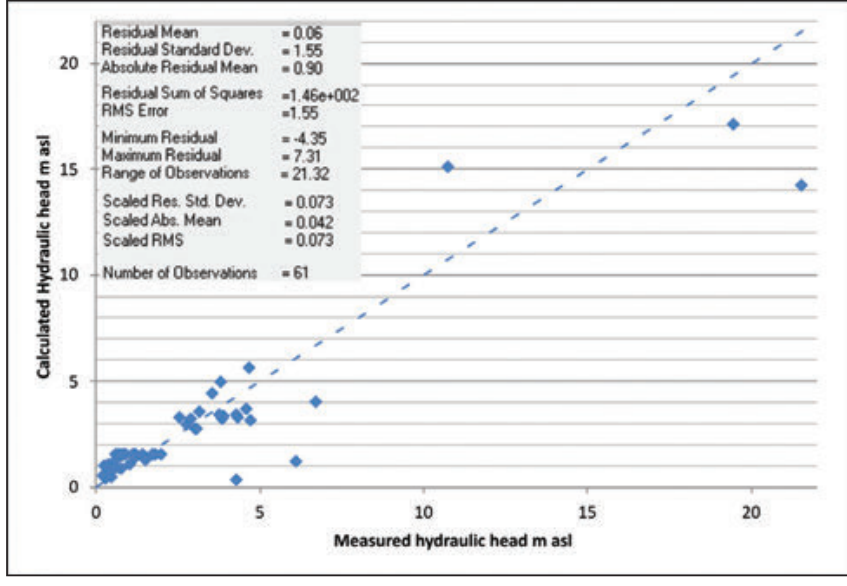

Fig. 19 - Scatterplot of calculated and observed heads and statistics.

Fig. 19 - . Grafico dei valori simulati vs osservati e relative statistiche.

\section{Discussion and Conclusion}

The Mizieb-Pwales NECoM made use of qualitative information and data acquired by archive research. Information/ assumption were introduced as "prior information" while the available measurements were introduced as classical "observations". The information content of both qualitative and quantitative data was assimilated along the calibration process, with the aim to highlight the remaining uncertainties because of data insufficiency. Therefore results should not be seen just as a mere trial to simulate a complex behaviour with poor data set, rather as an attempt to show the main conceptual model incongruences or open questions. It is also important to highlight that coastal hydraulic heads should never be used in constant-density numerical modelling without the freshwater head correction (Jiao and Post 2019).
In details, research results are highlighted below:

1. The geological setting of the two aquifers strongly influences the groundwater flow. As the sensitivity analysis shows (Fig. 15), the structural control of faults plays a key role in controlling groundwater flow directions and exchanges among aquifers, which was formerly used to be assumed as negligible.

2. The Mizieb potentiometric surface (Fig. 20) could be obtained only under the assumption that the MiziebMistra Fault does not prevent lateral recharge from the North; early runs failed in terms of unreliable simulated heads and numerical stability.

3. The Mizieb observed heads, even if uncertain, indicated the occurrence of a steep hydraulic gradient between the valley and the ridge. As the existence of a perched groundwater flow can be excluded by reading available stratigraphic logs (Constain Ltd 1957) therefore the presence of a further fault with a strong hydrogeological role was assumed (Fig. 13).

4. The controversial matter of Mizieb MSLA discharge seems to find confirmation in both the Constain Ldt (1957) and Morris (1952) hypotheses: given the vertical hydraulic gradient, the leakage can happen both from the sinkholes and the breccia fault. In addition, a third possible way out consists in lateral outflows towards Pwales CA.

5. The analysis of residuals in Pwales area shows a systematic overestimate of head values in the central-eastern portion of the aquifer (Fig. 20) under the regularization constraints. This implies different causes or their combination: (i) prior information assigned on the basis of the UCL properties are underestimated; (ii) the assigned agricultural well abstraction rates are underestimated; (iii) error due to the non-corrected freshwater heads dominates this aquifer (in case of seawater intrusion, the

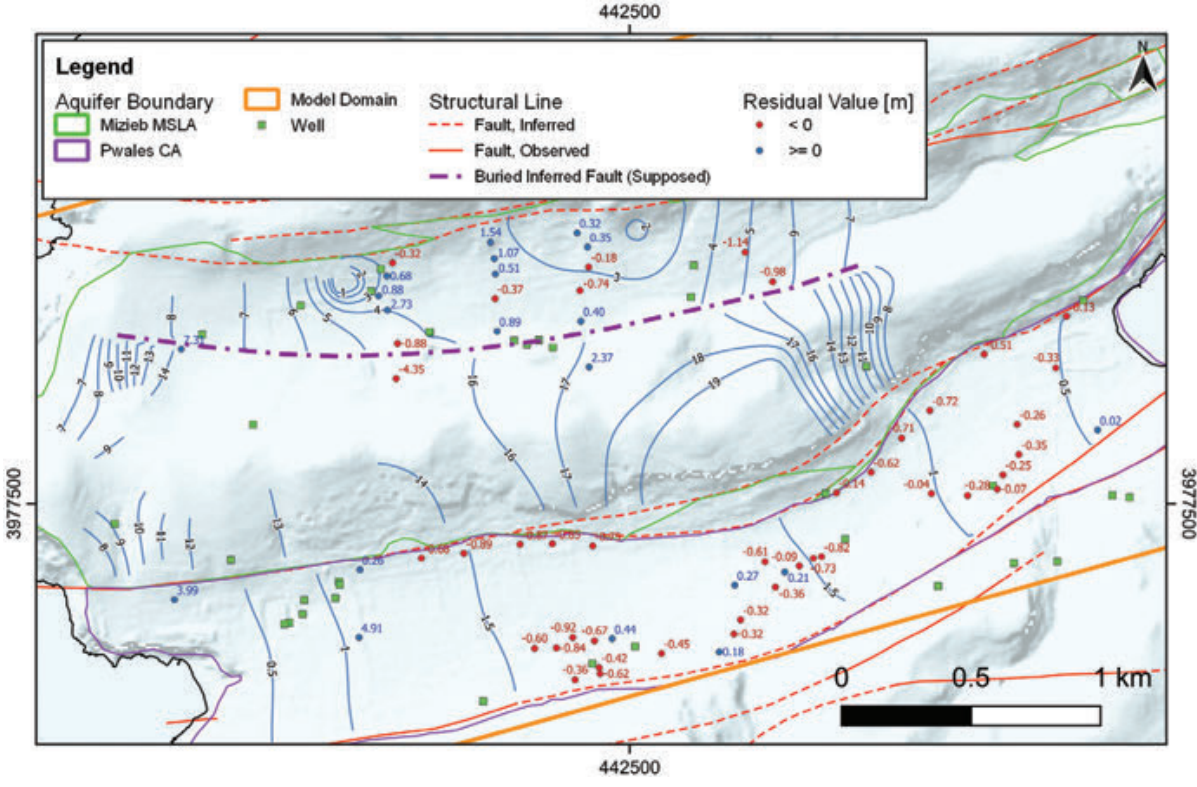

Fig. 20 - Hydraulic head residual values in observation points (red: simulated bigher than observed; blue: simulated lower than observed) and potentiometric lines in $m$ asl.

Fig. 20 - Valori dei residui dei carichi idraulici nei punti di osservazione (rosso: simulato superiore a quello osservato; blu: simulato inferiore a quello osservato) e linee equipotenziali in $\mathrm{m}$ slm. 
correction would rise the observed heads reducing the present residuals).

6. In the Western portion of Pwales CA, simulated heads are lower than observed ones (Fig. 20); in the same area, fault $\mathrm{Hfb} 5$ presents the highest sensitivity among all the estimated parameters (Fig. 15) with pp75 and pp63 generating two "bubbles" with opposite tendency to adjust the hydraulic conductivity value (Fig.18) which could point a likely local lateral contribution coming from Mizieb MSLA to Pwales CA.

7. In case of both aquifers, the adjusted parameter field (Fig. 18) clearly cannot be considered representative of the actual aquifer properties; its only purpose is to highlight conceptual model "bugs" as explained in point 6.

The present work tested the assumptions of the existing conceptual models and indicated new hypothesis to be verified (Fig. 21). The planning of field investigations and monitoring network, currently under development, should consider the aspects highlighted herein in order to clarify and validate the assumptions made. In case field activities would not be able to "say the last word", these aspects will have to be addressed through proper uncertainty analysis (where unknown data are not hidden but declared and quantified) since they are relevant to salient decision-making predictions.

Acknowledgment: This work was financed by the Energy and Water Agency of the Government of Malta, and is part of a larger project co-financed by the European Union under the LIFE Programme, LIFE-IP-RBMP-Malta - Optimising the implementation of the 2nd RBMP in the Maltese River Basin District (project reference: LIFE16 IPE/MT/000008). We wish to thank the three anonymous reviewer for their precious comments and suggestions.

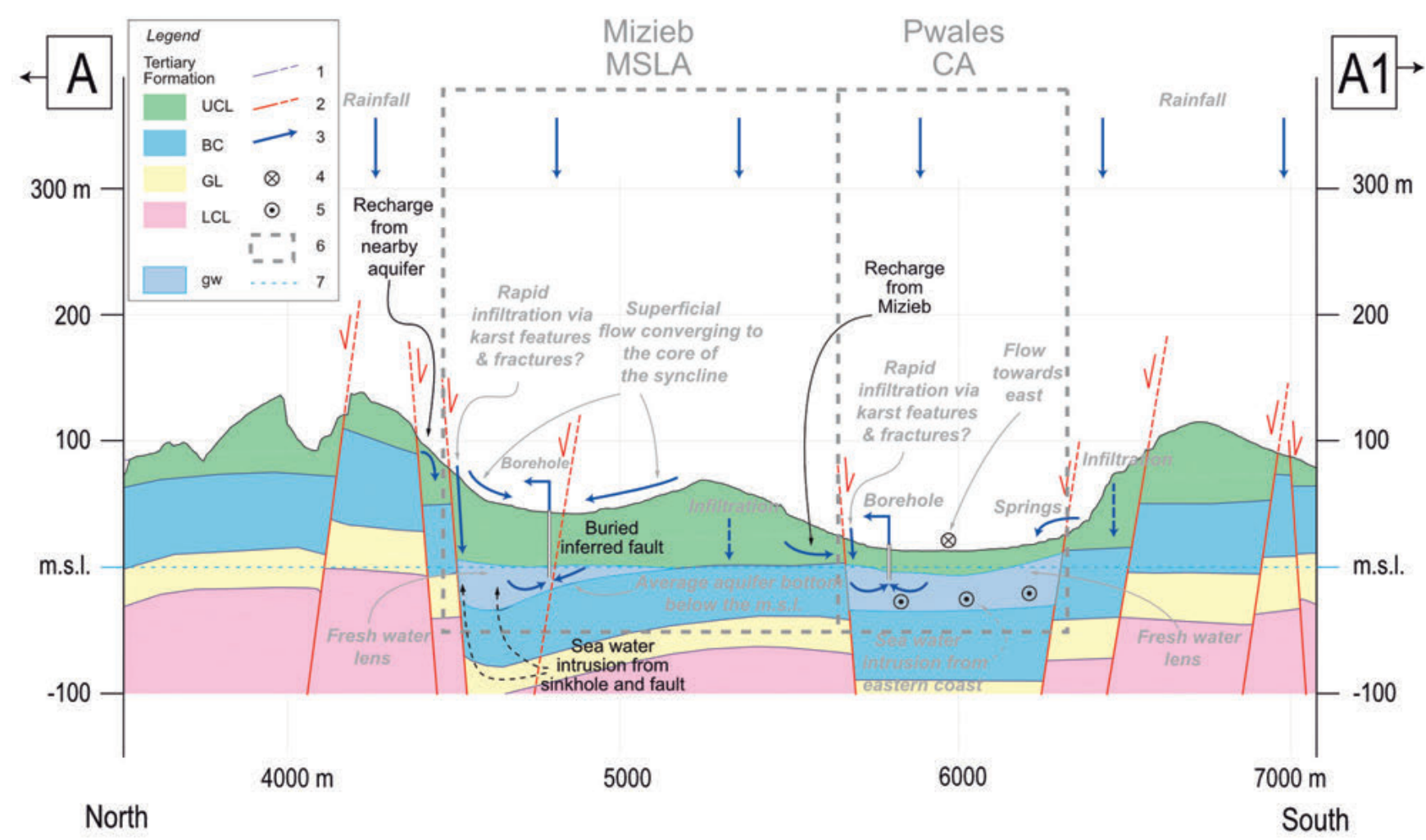

Fig. 21 - Updated (but not finished) Mizieb and Pwales aquifers bydrogeological conceptual scheme along section A-A1 (Figure 3): filled polygons - bydrogeological units; 1 bydrogeological units contacts; 2 - faults (observed or inferred); 3 - flow directions; 4 - superficial and groundwater flowpath towards the eastern sea coast; 5 - Sea water intrusion from the eastern coast; 6 - Areas of interest; 7 - Sea level. The grey labels represent the assumption made at the conceptual stage, before the NECoM.

Fig. 21 - Schema concettuale idrogeologico aggiornato (ma non definitivo) degli acquiferi di Mizieb e Pwales lungo la sezione A-A1 (Figura 3): poligoni pieni - unità idrogeologiche; 1 - contatti unità idrogeologiche; 2 - faglie (osservate o presunte); 3 - direzioni di flusso; 4 - percorso delle acque superficiali e sotterranee verso la costa del mare orientale; 5 - Intrusione di acqua di mare dalla costa orientale; 6 - Aree di interesse; 7 - Livello del mare. I livelli grigi rappresentano l'ipotesi formulata nella fase concettuale, prima del NECoM. 


\section{REFERENCES}

Borsi I, Foglia L, Cannata M, Vázquez-Suñé E, Mehl S, De Filippis G, Criollo R, Ghetta M, Cardoso M, Velasco V, Neumann J, Toegl A, Serrano A, Riera C, Rossetto R (2019) FREEWAT User Manual, Volume 0 - Reference Manual. Version 1.2.0, November 14th, 2019, http://www.freewat.eu/ - last accessed October 2020.

Bureau de Recherche Géologique et Minière - BRGM (1991) Study of the fresh-water resources of Malta. Water Works Department. Protocol number: R33691 EAU 4S 91. Energy and Water Authority archive, Malta.

Costain LTD (1958) Report on Geological Investigation of the Miziep Basin. Government of Malta - Water Supply, September 1958.

De Filippis G, Borsi I, Ghetta M, Rossetto R (2017) The FREEWAT platform for the assessment of water availability and quality. Acque Sotterranee - Italian Journal of Groundwater, 6(3/149):65-66, in Italian. doi:10.7343/as-2017-294.

Doherty J (2003) Groundwater model calibration using Pilot Points and Regularization. Ground Water. doi:10.1111/j.1745-6584.2003. tb02580.x

Doherty J (2008) Guidelines for groundwater model calibration using regularized inversion: Brisbane, Australia, Watermark Numerical Computing, 41 p., https://pesthomepage.org/. - last accessed October 2020.

Doherty J (2015) Calibration and Uncertainty Analysis for Complex Environmental Models. Watermark Numerical Computing, Brisbane, Australia. ISBN: 978-0-9943786-0-6

Doherty J, Fienen M, Hunt R (2010a) Approaches to highly parameterized inversion: Pilot-point theory, guidelines, and research directions: U.S. Geological Survey Scientific Investigations Report 2010-5168, https://pubs.usgs.gov/sir/2010/5168/pdf/ sir20105168.pdf- last accessed 18/03/2021

Doherty J, Hunt R, Tonkin M (2010b) Approaches to highly parameterized inversion: A guide to using PEST for modelparameter and predictive-uncertainty analysis. U.S. Geological Survey Scientific Investigations Report 2010-5168, https:// pubs.usgs.gov/sir/2010/5211/pdf/uncpest_sir2010-5211.pdf - last accessed 18/03/2021

Geological Survey of Great Britain GSGB (1945) Military Engineering: Water supply. Supplement No. 1. The location of underground water by geological and geophysical methods. War Office Code 7490. HMSO, London.

Government of Malta (2020) Electronic material from the Energy and Water Agency database

Harbaugh AW (2005) MODFLOW-2005, The U.S. Geological Survey modular ground-water model-the Ground-Water Flow Process: U.S. Geological Survey Techniques and Methods 6-A16.

Hill MC and Tiedeman CR (2007) Effective Groundwater Model Calibration: with Analysis of Data, Sensitivities, Predictions, and Uncertainty, John Wiley and Sons, New York. doi:10.1002/0470041080
Jiao J, Post V (2019) Coastal Hydrogeology. Cambridge: Cambridge University Press. doi:10.1017/9781139344142

Kresic N, Mikszewski A (2012) Hydrogeological Conceptual Site Models: Data Analysis and Visualization (1st ed.). CRC Press. https://doi.org/10.1201/b12151

Lang DM (1960) Soils of Malta and Gozo. Colonial Research Series N.29, London: HMSO.

Lotti F, Borsi I, Guastaldi E, Barbagli A, Basile P, Favaro L, Mallia A, Xuereb R, Schembri M, Mamo JA, Sapiano M (2021) Numerically enhanced conceptual modelling (NECoM) applied to the Malta Mean Sea Level Aquifer. Hydrogeology Journal, DOI: 10.1007/ s10040-021-02330-2.

Morris TO (1952). The water supply resources of Malta. Government of Malta.

National Statistics Office - Malta - NSO (2019). News Release 108/2019, 10 July 2019, https://nso.gov.mt/en/News_Releases/ View_by_Unit/Unit_C5/Population_and_Migration_Statistics/ Documents/2019/News2019_108.pdf. - last accessed October 2020

OED Oil Exploration Directorate, Office of the Prime Minister (1993) Geological Map of the Maltese Islands: Sheet 1- Malta.

Rose E (2012). Groundwater as a military resource: Development of Royal Engineers Boring Sections and British military hydrogeology in World War II. Geological Society of London Special Publications. 362. 105-138. 10.1144/SP362.7

Rossetto R, De Filippis G, Borsi I, Foglia L, Cannata M, Criollo R, Vázquez-Suñé E (2018) Integrating free and open source tools and distributed modelling codes in GIS environment for data-based groundwater management, Environmental Modelling \& Software, 107:210-230. doi:10.1016/j.envsoft.2018.06.007

Royal Engineers (1952) Boreholes drill performed from 1943 - 1952 for groundwater resource exploration in Malta. Energy and Water Authority archive, Malta.

Rumbaugh J and Rumbaugh O (2020) Groundwater Vistas Version 7.24, Build 211. Environmental Simulations Inc., Reinholds, PA.

Stuart ME, Heaton THE, Maurice L, Chilton PJ and William PJ (2008) A preliminary study on the identification of the sources of nitrate contamination in groundwater in Malta Results and interpretation. British Geological Survey Commissioned Report, CR/08/094. 4pp.

Sustainable Energy and Water Conservation Unit - SEWCU (2015) The 2nd Water Catchment Management Plan for the Malta Water Catchment District 2015 - 2021. Environment and Resources Authority, Spencer Hill Marsa, Malta.

Thornthwaite CW, Mather JR (1955) The Water Balance. Publications in Climatology, Laboratory of Climatology, Vol. 8, No. 1, 104 pp.

USDA - Soil Survey Staff. (1999) Soil taxonomy: A basic system of soil classification for making and interpreting soil surveys. 2nd edition. Natural Resources Conservation Service. U.S. Department of Agriculture Handbook 436.

Viaroli S, Lotti F, Mastrorillo L, Paolucci V, Mazza R (2019) Simplified two dimensional modelling to constrain the deep groundwater contribution in a complex mineral water mixing area, Riardo Plain, southern Italy. Hydrogeology Journal (2019) 27:1459-1478. https:// doi.org/10.1007/s10040-018-1910-3 